\title{
Immunocytochemical study of anti-Müllerian hormone in sheep ovarian follicles during fetal and post-natal development
}

\author{
J. Bézard, B. Vigier*, D. Tran*, P. Mauléon and Nathalie Josso* \\ Station de Physiologie, Institut National de la Recherche Agronomique, Nouzilly, 37380 Monnaie, \\ and ${ }^{*}$ Unité de Recherches sur l'Endocrinologie du Développement, INSERM, Hôpital des \\ Enfants-Malades, 75743, Paris cedex 15, France
}

\begin{abstract}
Summary. Anti-Müllerian hormone (AMH) was detected in perinatal and postnatal sheep ovaries, using avidin-biotin immunohistochemistry with a monoclonal antibody specific for ruminant AMH. Immunoreactivity was limited to granulosa cells, and was influenced both by the degree of follicular development, and by the age of the animal. In the fetus, only the most advanced follicles exhibited a faint immunoreactivity at 120 days gestation, and no reaction was observed in younger animals. Immediately before and after birth, primordial follicles were still negative, but a faint reaction was elicited in young growing follicles, increasing with follicle size. Strong immunoreactivity was visible in antral follicles, especially in the innermost granulosa cell layers, close to the oocyte and lining the antral cavity.
\end{abstract}

\section{Introduction}

Production of anti-Müllerian hormone (AMH), a glycoprotein of Sertoli cell origin (Blanchard \& Josso, 1974; Tran \& Josso, 1982; Hayashi et al., 1984) which mediates the regression of Müllerian ducts by the fetal testis (Jost, 1953), is not a male prerogative. Anti-Müllerian activity has been demonstrated in the chick embryonic and adult ovary (Hutson et al., 1981) and bioactive AMH released by granulosa cells has been purified from follicular fluid of mature bovine ovaries (Vigier et al., 1984). Using a sensitive immunocytochemical method, based on a monoclonal antibody specific for ruminant AMH, we have examined the ontogeny of ovarian AMH during fetal and postnatal development in the ewe and the influence of follicle and granulosa cell maturation upon AMH immunoreactivity.

\section{Materials and Methods}

Ovaries were obtained immediately after slaughter from developing sheep (Romanov-Préalpes breed), from 70 days of gestation to adulthood (Table 1). Fetal testes were also taken at 46, 60 and 100 days of gestation, for use as positive controls. For morphological examination, ovaries were fixed $1 \mathrm{~h}$ at $4^{\circ} \mathrm{C}$ in $2.5 \%$ buffered gluteraldehyde, post-fixed in $1 \%$ osmium tetroxide for $1 \mathrm{~h}$ at room temperature and embedded in Epon 812. Sections of $1 \mu \mathrm{m}$ were stained with $1 \%$ aqueous toluidine blue. For immunochemical study, whole fetal gonads and $5 \mathrm{~mm}^{3}$ blocks of post-natal ovaries were fixed in sodium phosphate buffer, $0 \cdot 1 \mathrm{M}, \mathrm{pH} 7 \cdot 4$, containing $2 \%$ paraformaldehyde, $1 \cdot 5 \% \mathrm{~L}(+)-1$ sine monochlorhydrate, $0 \cdot 2 \%$ sodium metaperiodate and saponin (Sigma Chemicals, St Louis, MO, U.S.A.), 0.02\% for fetal and $0.04 \%$ for post-natal tissue, for $2 \mathrm{~h}$ at room temperature as described by McLean \& Nakane (1974). Fixation was followed by 3 washes of sodium phosphate buffer, $0.1 \mathrm{M}, \mathrm{pH} 7 \cdot 4$, at $4^{\circ} \mathrm{C}$ over a $2-\mathrm{h}$ period. The specimens were then placed for $1 \mathrm{~h}$ at room temperature in the same buffer containing $10 \%$ dimethylsulphoxide, frozen and stored in liquid nitrogen until processed. Cryostat sections of $10 \mu \mathrm{m}$ were recovered on gelatin-coated slides.

Sections were washed for $1 \mathrm{~h}$ at room temperature in Dulbecco phosphate-buffered saline (PBS) (Dulbecco A, Biolyon, Dardilly, France), immersed for $5 \mathrm{~min}$ in $3 \%$ hydrogen peroxide to neutralize endogenous peroxidase, and washed again in PBS, 3 times 5 min each. They were then incubated in $10 \%$ ovalbumin solution to minimize nonspecific reactions, drained, and exposed overnight at $4^{\circ} \mathrm{C}$ to monoclonal antibody 61 , diluted $4 \mu \mathrm{g} / \mathrm{ml}$ in PBS containing $0.1 \%$ ovalbumin and $0.05 \%$ saponin. Monoclonal antibody 61 is a mouse IgGl, with an affinity constant of 
$5.8 \times 10^{-9} \mathrm{M}$ towards bovine AMH, and it is zoospecific for ruminant AMH (Legeai et al., 1986). After washing in PBS, the sections were incubated for $2 \mathrm{~h}$ at room temperature in biotinylated horse immunoglobulin directed against mouse IgG (Amersham-France, Les Ulis) at the 1/300 dilution recommended by the manufacturer, rinsed again in PBS, and incubated for $1 \mathrm{~h}$ in streptavidin-biotinylated peroxidase complex (Amersham). The sections were rinsed in PBS, and peroxidase was revealed in diaminobenzidine, $0.05 \%$ in PBS containing $0.035 \%$ hydrogen peroxide. Finally, the sections were washed in distilled water, post-stained with methyl green, dehydrated, mounted and examined under the light microscope. Sections of fetal ovine testicular tissue were included in each series to serve as positive control of the reaction. Negative controls, also performed for each batch, were obtained by substituting non-immune mouse immunoglobulin, or monoclonal antibody exhausted by an excess of bovine AMH, for the first antibody.

\section{Results}

Results are summarized in Table 1.

Table 1. Immunocytochemical reaction for AMH in sheep ovarian follicles at various ages

\begin{tabular}{|c|c|c|c|c|}
\hline \multirow[b]{2}{*}{ Age (days) } & \multirow{2}{*}{$\begin{array}{l}\text { No. of } \\
\text { gonads } \\
\text { studied }\end{array}$} & \multicolumn{3}{|c|}{$\begin{array}{l}\text { Immuno-reactivity of granulosa } \\
\text { cells in follicles: }\end{array}$} \\
\hline & & Primordial & $\begin{array}{l}\text { Growing and } \\
\text { preantral }\end{array}$ & Antral \\
\hline 70 post coitum & 2 & - & None & None \\
\hline 100 post coitum & 4 & - & - & None \\
\hline 120 post coitum & 2 & - & \pm & None \\
\hline 144 post coitum & 2 & - & $\bar{t}$ & + \\
\hline Birth* & 6 & - & $+\dagger$ & + \\
\hline 8 post partum & 4 & - & + & + \\
\hline 97 post partum & 2 & - & + & + \\
\hline 145 post partum & 2 & - & + & + \\
\hline Adult & 4 & - & + & + \\
\hline
\end{tabular}

${ }^{*}$ Birth $=145$ days post coitum.

$\dagger$ Positive in only 2 animals out of 3 .

\section{Peri- and post-natal ovaries}

All peri- and post-natal ovaries, from term to adulthood, contained follicles in all stages of development, i.e. primordial, growing and antral (Figs 1-4). The degree of AMH immunoreactivity was influenced by the stage of follicular maturation, but not by the age of the animal (Figs 5-10). No immunoreactivity was observed in primordial follicles, except in one experimental series, in which a faint reaction was detected in the cytoplasm of a few cuboidal granulosa cells. The proportion of growing follicles with detectable AMH increased with the degree of follicular development. Initially, in young growing follicles, all granulosa cell layers were faintly stained. As growth continued, immunoreactivity became stronger in the innermost layers close to the oocyte, and decreased in those adjoining the basal membrane. Most antral follicles, atretic ones excepted, were stained by the reaction for AMH. Stain deposition occurred in the cytoplasm of granulosa cells, particularly along the plasma membrane. The intensity of the immunocytochemical reaction varied with the location of the granulosa cells: peripheral cells exhibited little or no activity, while granulosa cells lining the antral cavity and the oocyte were strongly positive (Figs $5 \& 6$ ). Immunoreactive protrusions of the cumulus cells could be followed across the zona pellucida and perivitelline space, into the ooplasm. Groups of immunoreactive sloughed granulosa cells were occasionally seen in the cavity of large follicles. Thecal cells never exhibited a positive reaction. In granulosa cells, no reaction was observed using a non-specific first antibody, or anti-AMH monoclonal antibody exhausted by an excess of bovine AMH (Figs 11, 12 \& 13). 

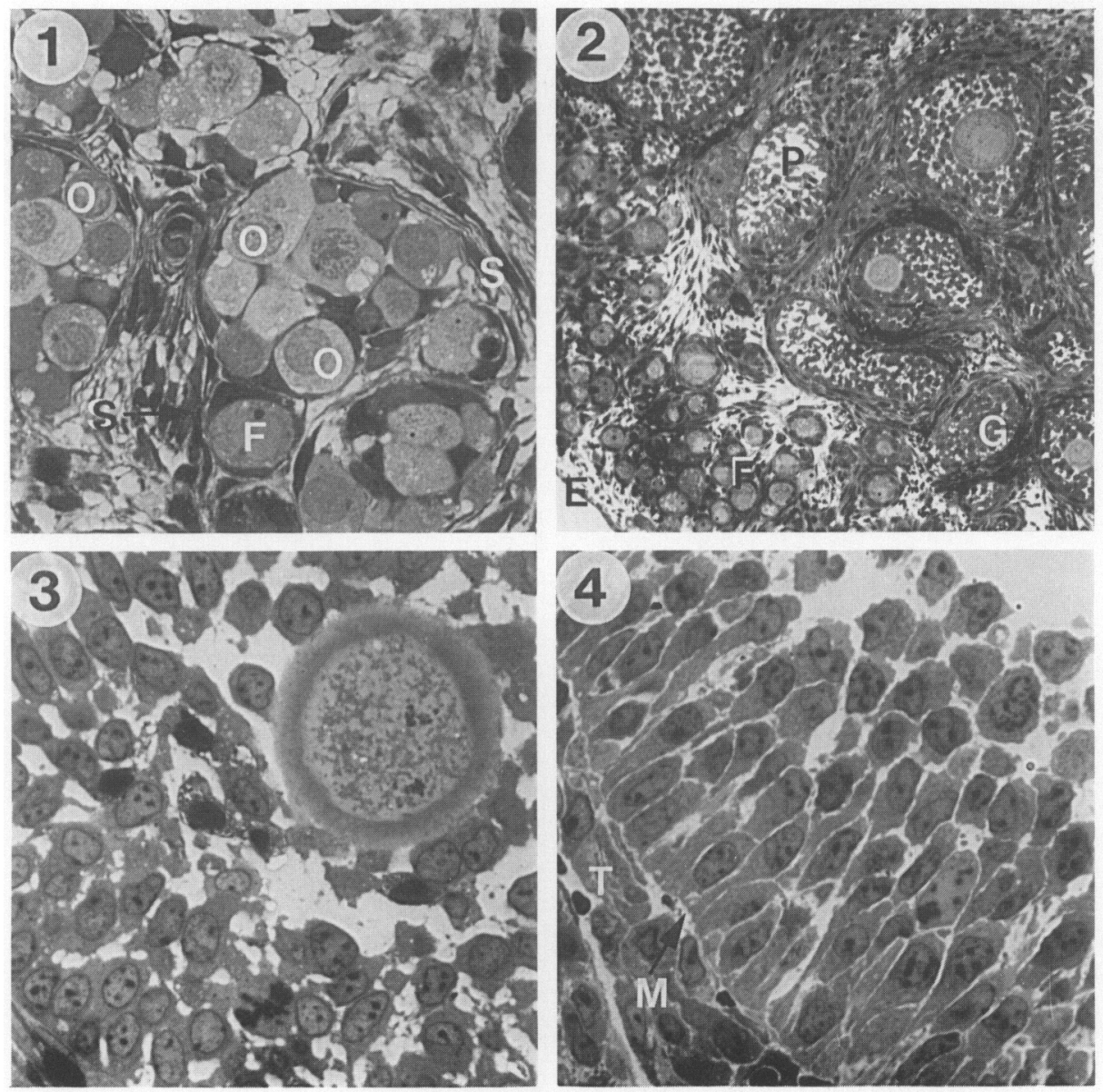

Figs 1-4. Plastic sections, $1 \mu \mathrm{m}$, toluidine blue.

Fig. 1. Fetal ovary, 70 days gestation, deep part of the gonad. Ovigerous cords, containing oocytes $(\mathrm{O})$ in meiotic prophase, are surrounded by flat somatic cells $(\mathrm{S})$. A single primordial follicle $(F)$ is visible. $\times 550$.

Fig. 2. Fetal ovary, 120 days gestation. Numerous primordial follicles (F) are packed against the surface epithelium $(E)$. Growing follicles $(G)$ and preantral follicles $(P)$ are located deeper in the gonad. $\times 100$.

Fig. 3. Dispersion of granulosa cells, some of which are pycnotic, herald antral formation, in a follicle from 120-day-old ovary. The nucleus is not visible on this section. Lipid droplets are present in the ooplasm. $\times 600$.

Fig. 4. Adult ovary. Wall of an antral follicle, limited by a basal membrane (M), lined by thecal cells $(T) . \times 180$.

\section{Prenatal ovaries}

Fetal ovaries of 70 days of gestation exhibited numerous ovigerous cords, containing oogonia and oocytes in meiotic prophase (Fig. 1). A few primordial follicles with oocytes at the dictyate stage had differentiated in the deepest part of the gonad and were surrounded by flattened somatic 

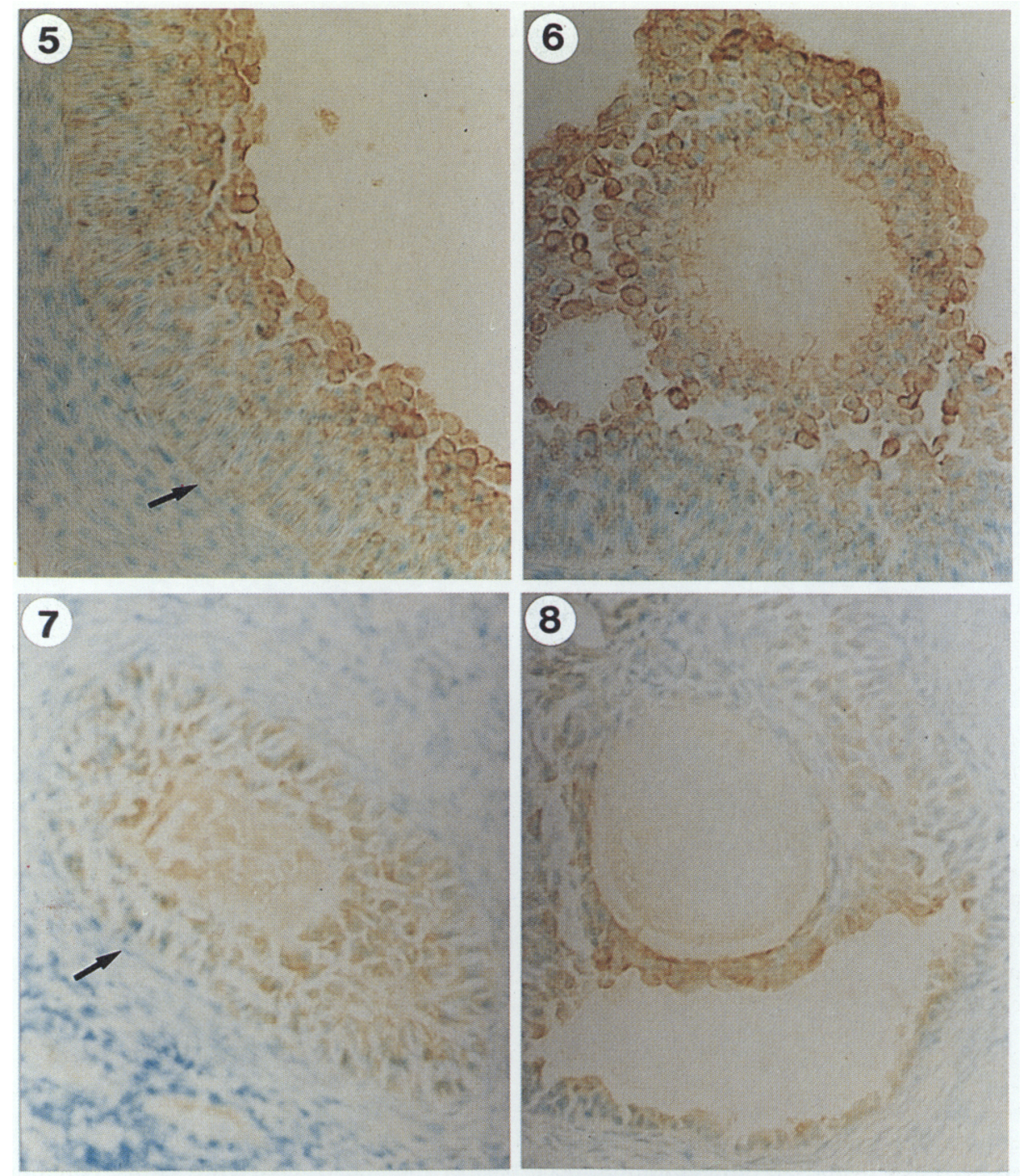

9
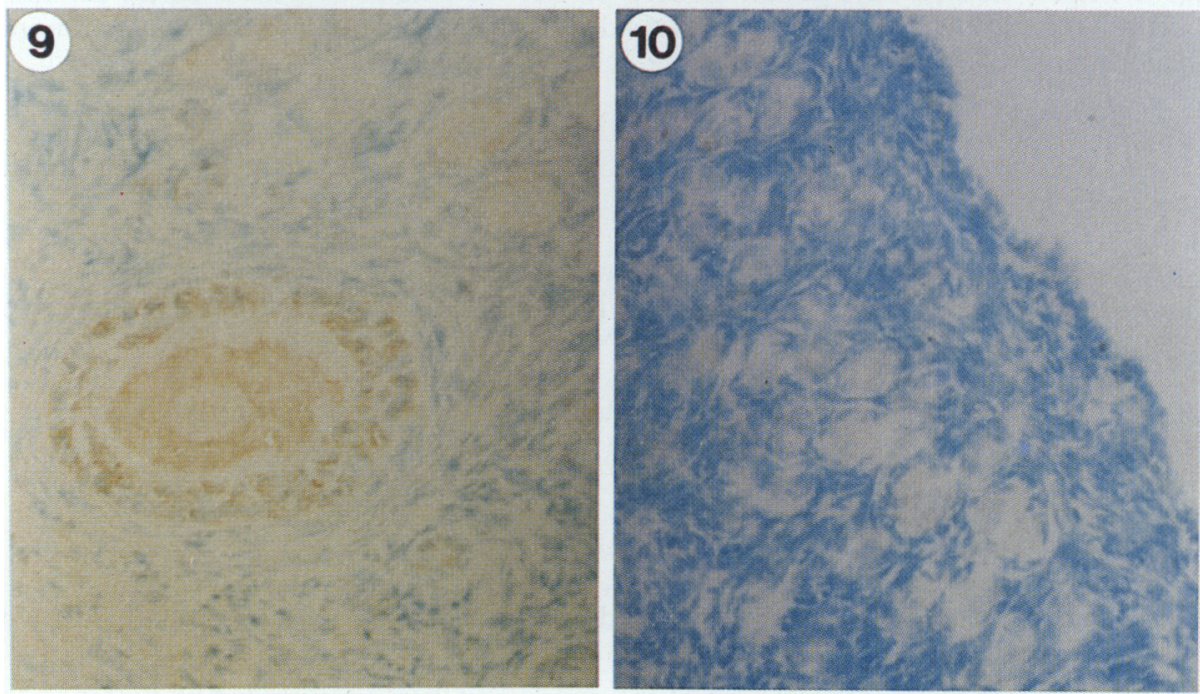
cells. At 100 days of gestation, all germ cells were enclosed in primordial follicles. At 120 days, growing follicles with 2-6 granulosa cell layers could be found in the innermost regions; in some, dispersion of granulosa cells heralded the appearance of an antral cavity (Figs 2 \& 3). Faint immunoreactivity could occasionally be detected in a few cells belonging to preantral follicles, but was absent from the somatic cells of ovigerous cords, primordial and growing follicles (Figs 7-10).

\section{Fetal testicular tissue}

Intense AMH-specific immunoreactivity, much higher than that elicited in granulosa cells at any age, was invariably present in the Sertoli cell cytoplasm of fetal testicular tissue, at 46, 60, and 100 days of gestation (Fig. 14).

\section{Discussion}

Ovarian and testicular AMH have similar bio- and immunoreactivity (Vigier et al., 1984), but the amount and timing of their secretion are apparently different. High amounts of AMH are produced by immature Sertoli cells, beginning at the time of seminiferous tubule formation, while adult Sertoli cells release only token quantities of the hormone (Vigier et al., 1983). Adult granulosa cells are also poor producers of AMH (Vigier et al., 1984). Using a monoclonal antibody specific for ruminant AMH (Legeai et al., 1986) and a sensitive streptavidin-biotin technique, we show that fetal granulosa cells are even less competent in this respect, since AMH could be detected in the fetal ovary only shortly before birth. The specificity of the immunocytochemical reaction is proven by the capacity of purified AMH to abolish the reaction, when it is used to exhaust the first antibody (Fig. 13). These results contrast with those reported by Hutson et al. (1981) for the chicken, in which embryonic and post-natal ovarian tissue exhibit comparable anti-Müllerian bioactivity. The detection of immunoreactivity in the cytoplasm of granulosa cells of adult sheep is in keeping with the detection of immunoreactive AMH in bovine follicular fluid (Vigier et al., 1984; Necklaws et al.,

Figs 5-10. Cryostat sections, $10 \mu \mathrm{m}$, stained by methyl green and immunohistochemical reaction for $\mathrm{AMH}, \times 260$.

Fig. 5. Antral follicle of a 97-day-old post-natal ovary. Note the immunoreactivity gradient: reaction is strongest in granulosa cells lining the antral cavity, and extremely faint in those close to the basal membrane (arrow).

Fig. 6. Same follicle, as in Fig. 5: strong reaction in cumulus cells.

Fig. 7. Growing follicle on the day of birth. Note the immunoreactivity gradient. The reaction is stronger in the granulosa cells near the oocyte, and weaker in those close to the basal membrane (arrow).

Fig. 8. Antral follicle in perinatal ovary, 144 days gestation. Reaction is localized to granulosa cells lining the oocyte and the antrum.

Fig. 9. Growing follicle, with 2 layers of granulosa cells, in perinatal ovary, 144 days gestation. Positive reaction in granulosa cells.

Fig. 10. Primordial follicles in fetal ovary, of 100 days gestation. No immunoreactivity is observed. 

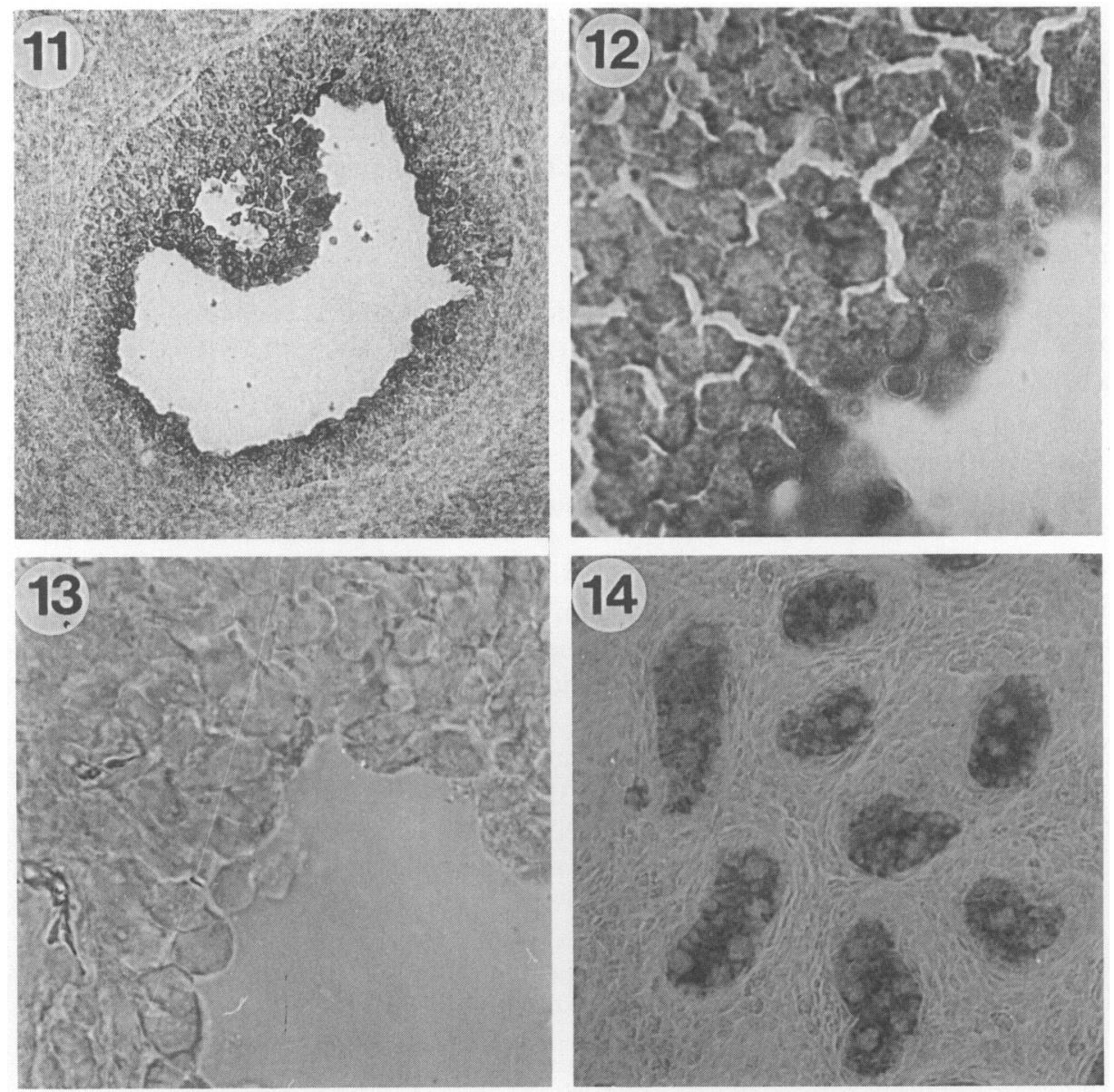

Figs 11-14. Cryostat section, $10 \mu \mathrm{m}$, stained by immunohistochemical reaction for AMH.

Fig. 11. Antral follicle in adult ovary. A strong reaction is visible in granulosa cells in the cumulus and in those lining the antrum. Thecal cells are negative. $\times 125$.

Fig. 12. Same follicle as in Fig. 11: positive reaction. $\times 650$.

Fig. 13. Same follicle as in Fig. 11, next section, stained with first antibody exhausted with bovine $\mathrm{AMH}$. The positive reaction is abolished. $\times 650$.

Fig. 14. Fetal testis, 100 days gestation. Sertoli cells of seminiferous tubules exhibit a strongly positive reaction. $\times 210$.

1986) and in the incubation medium of bovine granulosa cells (Vigier et al., 1984), thus confirming the close physiological relationship which exists between somatic cells of male and female gonads (Fritz, 1982).

Takahashi et al. (1986) have published an immunochemical study of the ontogeny of AMH in granulosa cells of heifers from 1 day to 5 years of age. Fetuses were not studied. These investigators detected AMH immunoreactivity in the granulosa cells of Graafian follicles at all ages, but did not mention the existence of an immunoreactivity gradient between mural and periantral granulosa cells. 
The degree of maturation of the follicle, and the position of granulosa cells within the follicle also modulate their capacity for AMH production. No AMH was detected in the somatic cells lining primordial follicles, except in one case, characterized by the cuboidal morphology of granulosa cells. Mariana \& de Pol (1986) have shown in the rabbit that primordial follicles about to grow are surrounded by cuboidal cells. The degree of immunoreactivity of granulosa cells of small antral follicles was not higher than that observed in large follicles, supporting the hypothesis that the lower concentration of AMH in follicular fluid of large than small follicles (Vigier et al., 1984; Necklaws et al., 1986) is due to the fact that in the later stages of follicle growth, antral fluid volume increases at a faster rate than granulosa cell number (McNatty, 1981).

Progression of follicle maturation was dccompanied by an accentuation of the gradient between mural granulosa cells on one hand, which exhibit low or absent AMH immunoreactivity, and granulosa cells lining the antrum and in the cumulus oophorus on the other, which have a consistently high AMH content. The heterogeneity of the granulosa cell population is well known. Studies carried out in the rat show that during Graafian follicle growth, only granulosa cells in the cumulus proliferate (Hirshfield \& Midgley, 1984), and can be considered as stem cells. When challenged by $\mathrm{FSH}$, peripheral granulosa cells located near the basal lamina undergo terminal cytodifferentiation, characterized by acquisition of $\mathrm{LH} / \mathrm{hCG}$ receptor, steroidogenic enzymes and lipid droplets (reviewed by O'Shea, 1981; Erickson et al., 1985), whereas prolactin receptor development and reactivity to a monoclonal antibody raised to a mammary cell line (Erickson et al., 1985) is restricted primarily to the cumulus and the innermost granulosa cells. There is evidence, reviewed by Erickson (1983), that supports the hypothesis that the position of the granulosa cell in the follicle determines in which way it will differentiate in response to FSH stimulation. Our results show that $\mathrm{AMH}$ immunoreactivity is confined to the stem cell population of granulosa cells incapable of undergoing terminal differentiation under FSH stimulation. The apparent differences in the ontogeny of AMH between Sertoli and granulosa cells can therefore be resolved, since in both cases only immature cells express the hormone. Neither testosterone nor FSH appear to regulate AMH secretion by the Sertoli cell in vitro (Vigier et al., 1985). FSH is probably not implicated either in AMH production by granulosa cells. In the sheep fetus, FSH concentrations fall after 130 days of gestation (Sklar et al., 1981), close to the time of initiation of AMH production by granulosa cells, but the pubertal rise in FSH values does not affect AMH content of granulosa cells. Finally, the main difference between Sertoli and granulosa cells lies in the ontogeny of AMH release. Sertoli cells produce AMH immediately after their differentiation in the fetal testis (Tran et al., 1977), whereas granulosa cells of fetal ovaries do not contain immunocytochemically detectable AMH. The production of AMH is curtailed at puberty in the testis (Vigier et al., 1983), but remains stable in the ovary.

Does AMH play a physiological role in the ovary? Because it is produced only relatively late in development, at a time when Müllerian ducts have become resistant to its action, it cannot impede Müllerian development. Bovine AMH which is probably the testicular factor responsible for the sterilization and masculinization of the freemartin ovary (Jost et al., 1972), has been shown to inhibit the proliferation of rat oogonia in vitro but has no deleterious effect upon oocytes enclosed in primordial follicles (Vigier \& Josso, 1986). Two remaining possibilities must be considered. AMH could be the factor responsible for the arrest of the meiotic prophase at the dictyate phase in fetal oocytes enclosed in primordial follicles, but the absence of AMH immunoreactivity in granulosa cells of fetal ovaries does not favour this hypothesis. AMH could also be related in some way to the oocyte maturation inhibitor which holds meiosis in abeyance until ovulation (Vigier $e t$ al., 1984). The localization of AMH immunoreactivity in granulosa cells lining the antrum and the oocyte, and the immunoreactivity of the cumulus cell protrusions which extend across the zona pellucida into the germ cell cytoplasm (Gondos, 1970; Szöllösi, 1975), support this possibility, but up to now, no meiosis-inhibiting effects of purified bovine AMH have been demonstrated using rat oocytes as target organ (A. Tsafriri, J. Y. Picard and N. Josso, unpublished results). 
We thank Jacqueline Campargue for technical assistance and Catherine Dalleu for manuscript preparation. The work is supported by a grant from INRA/CNRS (Institut National de la recherche Agronomique/Centre National de la recherche Scientifique): ATP 'Hormones hypophysaires et fonctions de la reproduction chez les Vertébrés'.

\section{References}

Blanchard, M.G. \& Josso, N. (1974) Source of the antiMüllerian hormone synthesized by the fetal testis: Müllerian-inhibiting activity of fetal bovine Sertoli cells in tissue culture. Pediatr. Res. 8, 968-971.

Erickson, G.F. (1983) Primary cultures of ovarian cells in serum-free medium as models of hormone-dependent differentiation. Molec. cell. Endocr. 29, 21-29.

Erickson, G.F., Hofeditz, C., Unger, M., Allen, W.R. \& Dulbecco, R. (1985) A monoclonal antibody to a mammary cell line recognizes two distinct subtypes of ovarian granulosa cells. Endocrinology 117, $1490-1499$.

Fritz, I.B. (1982) Comparison of granulosa and Sertoli cells at various stages of maturation: similarities and differences. In Intraovarian Control Mechanisms, pp. 357-384. Eds C. P. Channing \& S. J. Segal. Plenum Press, New York.

Gondos, B. (1970) Granulosa cell-germ cell relationship in the developing rabbit ovary. J. Embryol. exp. Morph. 23, 419-426.

Hayashi, H., Shima, H., Hayashi, K., Trelstad, R. L. \& Donahoe, P. K. (1984) Immunocytochemical localization of Müllerian inhibiting substance in the rough endoplasmic reticulum and Golgi apparatus in Sertoli cells of the neonatal calf testis using a monoclonal antibody. J. Histochem. Cytochem. 32, 649-654.

Hirshfield, A.N., Midgley, A.R. (1984) Morphometric analysis of follicular development in the rat. Biol. Reprod. 19, 597-605.

Hutson, J.M., Ikawa, H. \& Donahoe, P.K. (1981) The ontogeny of Müllerian inhibiting substance in the gonads of the chicken. J. Pediatr. Surg. 16, 822-827.

Jost, A. (1953) Problems of fetal endocrinology: the gonadal and hypophyseal hormones. Recent Prog. Horm. Res. 8, 379-418.

Jost, A., Vigier, B. \& Prépin, J. (1972) Freemartins in cattle: the first steps of sexual organogenesis. $J$. Reprod. Fert. 29, 349-379.

Legeai, L., Vigier, B., Tran, D., Picard, J.Y. \& Jesso, N. (1986) Monoclonal antibodies raised against bovine anti-Müllerian hormone: bovine, ovine and caprine hormones share a set of identical epitopes. Biol. Reprod. 35, 1217-1225.

Mariana, J.C. \& de Pol, J. (1986) Analyse morphométrique de la population des follicules primordiaux de l'ovaire by Lapine de 30 jours. Archs Biol. (Bruxelles) 97, 139-156.

McLean, I.W. \& Nakane, P.K. (1974) Periodate-lysineparaformaldehyde fixative: a new fixative for immunoelectron microscopy. J. Histochem. Cytochem. 22, 1077-1083.

MeNatty, K.P. (1981) Hormonal correlates of follicular development in the human ovary. Aust. J. biol. Sci. 34, 249-268.
Necklaws, E.C., LaQuaglia, M.P., MacLaughlin, D., Hudson, P., Mudgett-Hunter, M. \& Donahoe, P.K. (1986) Detection of Müllerian inhibiting substance in biological samples by a solid phase sandwich radioimmunoassay. Endocrinology 118, 791-796.

O'Shea, J.D. (1981) Structure-function relationships in the wall of the ovarian follicle. Aust. J. biol. Sci. 34, 379-394.

Sklar, C.A., Mueller, P.L., Gluckman, P.D., Kaplan, A.M., Rudolph, A.M. \& Grumbach, M.M. (1981) Hormone ontogeny in the ovine fetus. VII. Circulating luteinizing hormone and follicle-stimulating hormone in mid- and late gestation. Endocrinology $108,874-880$.

Szöllösi, D. (1975) Ultrastructural aspects of oocyte maturation and fertilization in mammals. In $\mathrm{La}$ Fécondation, pp. 13-35. Ed. C. Thibault. Masson, Paris.

Takahashi, M., Hayashi, M., Manganaro, T.F. \& Donahoe, P.K. (1986) The ontogeny of Müllerian inhibiting substance in granulosa cells of the bovine ovarian follicle. Biol. Reprod. 35, 447-453.

Tran, D. \& Josso, N. (1982) Localization of anti-Müllerian hormone in the rough endoplasmic reticulum of the developing bovine Sertoli cell using immunocytochemistry with a monoclonal antibody. Endocrinology 111, 1562-1567.

Tran, D., Meusy-Dessole, N. \& Josso, N. (1977) AntiMüllerian hormone is a functional marker of foetal Sertoli cells. Nature, Lond. 269, 411-412.

Vigier, B. \& Josso, N. (1986) Use of monoclonal antibodies to anti-Müllerian hormone in the study of sexual differentiation. In Monoclonal Antibodies: Basic Principles, Experimental and Clinical Applications in Endocrinology, pp. 309-319. Eds G. Forti, M. D. Serio \& M. B. Lipsett. Raven Press, New York.

Vigier, B., Tran, D., Du Mesnil du Buisson, F., Heyman, Y. \& Josso, N. (1983) Use of monoclonal antibody techniques to study the ontogeny of bovine antiMüllerian hormone. J. Reprod. Fert. 69, 207-214.

Vigier, B., Picard, J.Y., Tran, D., Legeai, L. \& Josso, N. (1984) Production of anti-Müllerian hormone: another homology between Sertoli and granulosa cells. Endocrinology 114, 1315-1320.

Vigier, B., Picard, J.Y., Campargue, J., Forest, M.G., Heyman, Y. \& Josso, N. (1985) Secretion of antiMüllerian hormone by immature bovine Sertoli cells in primary culture, studied by a competition type radio-immunoassay: lack of modulation by either FSH or testosterone. Molec. cell. Endocr. 43, 141-150. 